\title{
Notices and Books
}

\section{BOOKS RECEIVED}

Multiple Sclerosis. Sigrid Poser, Springer-Verlag, Berlin, Heidelberg, New York, 1978. 93 pages. $\$ 18.00$

Radiculosaccography with Water Soluble Contrast Media. P. Capesius and E. Babin, Springer-Verlag, Berlin, Heidelberg, New York, 1978. 166 pages. $\$ 49.00$

The Benzodiazepines, Use, Overuse, Misuse, Abuse. John Marks, MTP Press Ltd., St. Leonard's House, Lancaster, England, 1978. 111 pages.

Fundamentals of Electroencephalography, Second Edition. Kenneth A. Kooi, Richard P. Tucker, Robert E. Marshall, Harper \& Row, Hagerstown, Md. U.S.A., 1978. 249 pages. $\$ 20.00$

The Pathophysiology of Spinal Cord Trauma. Jewell L. Osterholm, Charles C. Thomas, Springfield, 1978. 212 pages. $\$ 19.50$

Who Speaks for the Children. Peter Silverman, Musson Book Company, Don Mills, Ontario, 1978. 224 pages. \$8.95

Pediatric Neurology and Neurosurgery. Richard A. Thompson and John R. Green, S.P. Medical and Scientific Books, Jamaica, N.Y., 1978. 420 pages. $\$ 30.00$

Proceedings of the European Society for Neurochemistry, Volume 1, 2nd Meeting of the ESN Gottingen August 1978. Edited by V. Neuhoff, Verlag Chemie, New York, 1978. 658 pages. $\$ 47.60$

The Veins of the Posterior Fossa. A Wackenheim and J. P. Braun, forward by J. Bull, Springer-Verlag, Berlin, Heidelberg, New York, 1978. 156 pages. $\$ 68.00$

Ergot-Alkaloids and Related Compounds. B. Berde and H. O. Schild, Springer-Verlag, Berlin, Heidelberg, New York, 1978. 1003 pages. $\$ 140.00$

Advances in Anatomy, Embryology, and Cell Biology Ontogenesis of the Visual System, Volume 54, Fasc. 3. Karl J. Zilles, Springer-Verlag, Berlin, Heidelberg, New York, 1978. 138 pages. $\$ 24.00$

Manual for the Adult Neuropsychological Evaluation. Dennis Swiencinsky, Charles C. Thomas, Springfield, 1978. 191 pages. $\$ 16.75$

Transmethylations and the Central Nervous System. V. M. Andreoli, A. Agnoli, C. Fazio, Springer-Verlag, Berlin, Heidelberg, New York, 1978. 185 pages. $\$ 29.00$

Preoperative and Postoperative Care in Neurological Surgery. Burtun L. Wise, Charles C. Thomas, Springfield, 1978. 187 pages. $\$ 13.75$
Studies in Neurophysiology - Presented to A. K. McIntyre. Editor R. Porter, Cambridge University Press, New York and London, 1978. 440 pages. $\$ 75.00$

Persistent Pain - Modern Methods of Treatment, Volume 1. Editor Sampson Lipton, Academic Press, London, 1978. 272 pages. $\$ 20.50$

Biological Bases of Psychiatric Disorders. Alan Frazer and Andrew Winokur, Spectrum Publications, Inc., New York, London, 1977. 271 pages. $\$ 15.00$

Current Developments in Psychopharmacology, Volume 4. Edited by W. B. Essman and L. Valzelli, Spectrum Publications, Inc., New York, London, 1977. 296 pages. $\$ 25.00$

\section{Excerpta Medica Travel Award 1979}

The Trustees of the Excerpta Medica Foundation announce with great pleasure that applications may now be submitted for their Travel Award for 1979. The Award, which lasts for a period of three months and covers travel and hotel costs, is open to all categories of medical specialists. However, only candidates born during, or after, 1943 will be considered. If married, the recipient may also be accompanied by either husband or wife. The closing date for the receipt of applications is 1st March 1979. People wishing to be considered for this Award should write to:

\section{Mr. Kenneth Ellison Davis \\ Travel Award Office \\ Excerpta Medica Foundation \\ P.O. Box 1126 \\ 1000 BC Amsterdam \\ The Netherlands}

enclosing:

a. Curriculum Vitae (plus a recent photograph).

b. List of publications, plus reprints.

c. Two letters of recommendation.

d. A statement of approximately 250 words indicating how the Award would be used.

The Award will be conferred upon the recipient at a formal ceremony to be held in The Netherlands at an appropriate date in 1979. 